\title{
Modeling Nitrogen Decrease in Water Lettuce Ponds from Waste Stabilization Ponds
}

\author{
Gitta Agnes Putri ${ }^{1, *}$, and Sunarsih ${ }^{1,2}$ \\ ${ }^{1}$ Magister Program of Mathematics, Faculty of Science and Mathematics, Diponegoro University, Semarang - Indonesia \\ ${ }^{2}$ Doctoral Program of Environmental Science, School of Postgraduate Studies, Diponegoro University, Semarang-Indonesia
}

\begin{abstract}
This paper presents about the dynamic modeling of the Water Lettuce ponds as a form of improvement from the Water Hyacinth ponds. The purpose of this paper is to predict nitrogen decrease and nitrogen transformation in Water Lettuce ponds integrated with Waste Stabilization Ponds. The model consists of 4 mass balances, namely Dissolved Organic Nitrogen (DON), Particulate Organic Nitrogen (PON), ammonium $\left(\mathrm{NH}_{4}{ }^{+}\right)$, Nitrate and Nitrite $\left(\mathrm{NO}_{\mathrm{x}}\right)$. The process of nitrogen transformation which considered in a Water Lettuce ponds, namely hydrolysis, mineralization, nitrification, denitrification, plant and bacterial uptake processes. Numerical simulations are performed by giving the values of parameters and the initial values of nitrogen compounds based on a review of previous studies. Numerical results show that the rate of change in the concentration of nitrogen compounds in the integration ponds of waste stabilization and water lettuce decreases and reaches stable at different times.
\end{abstract}

\section{Introduction}

Waters is one environment that has an important function for human life. But now, the supply of source life is increasingly limited and increasingly polluted by human activities. The increase of development activities in various fields, either directly or indirectly will affect the environmental damage, primarily pollution of waters environment originating from domestic and non domestic waste, such as factories and industries.

Waste is a mixture of household activities, offices and industries. The strength of the waste water is measured by BOD or COD. One of the important ingredients / compounds contained in the waste, especially liquid waste is the nitrogen compound [1].

Nitrogen is an important nutrient in biological systems. Nitrogen accounts for about 12 percent of bacterial protoplasm and 5 to 6 percent of mold protoplasm [2]. In water, the main source of nitrogen is not only in the form of gases, but rather inorganic and organic nitrogen. Inorganic nitrogen consists of ammonia $\left(\mathrm{NH}_{3}\right)$, ammonium $\left(\mathrm{NH}_{4}\right)$, nitrites $\left(\mathrm{NO}_{2}\right)$, nitrates $\left(\mathrm{NO}_{3}\right)$ and nitrogen molecules $\left(\mathrm{N}_{2}\right)$ in gaseous form. While organic nitrogen in the form of proteins, amino acids and urea. These nitrogen forms undergo a transformation, as part of the nitrogen cycle [3].

The high of nitrogen compounds in waters (wastewater) giving an impact, such as being able to stimulate unlimited algae growth and decrease dissolved oxygen content causing fish death. In addition, waste containing high of nitrate concentrations can also cause poisoning in infants and toddlers [4]. Therefore before re-use, processing is necessary until it reaches the permissible quality requirements.

In wastewater treatment processes, especially those containing organic compound pollutants, the most commonly used technology is the activity of microorganisms that can decompose organic pollutants, commonly called biological processes. One of the most widely used biological treatment processes is a waste stabilization pond system. This is due to the low cost and simplicity of construction, operation, and maintenance [5]. However, the main problem facing the operation of this pool is the minimal reduction in the amount of excessive nitrogen compounds in waste caused by algae activity especially during the summer.

Research on the transformation and decrease of nitrogen compounds has previously been widely, one of them is by using water hyacinth pond which is integrated with waste stabilization pond. However, the use of water hyacinth as a biofilter still has some deficiencies, namely the number of roots owned by water hyacinth, the growth of root buds and leaves which are relatively long, and requires a relatively wide place as a growing medium [6]. Therefore, this article provides an effective method for separating algae and other particles from waste in waste stabilization ponds by considering the shortcomings of water hyacinth, ie by the use of a water lettuce pond.

*Corresponding author: narsih_pdil@yahoo.com 


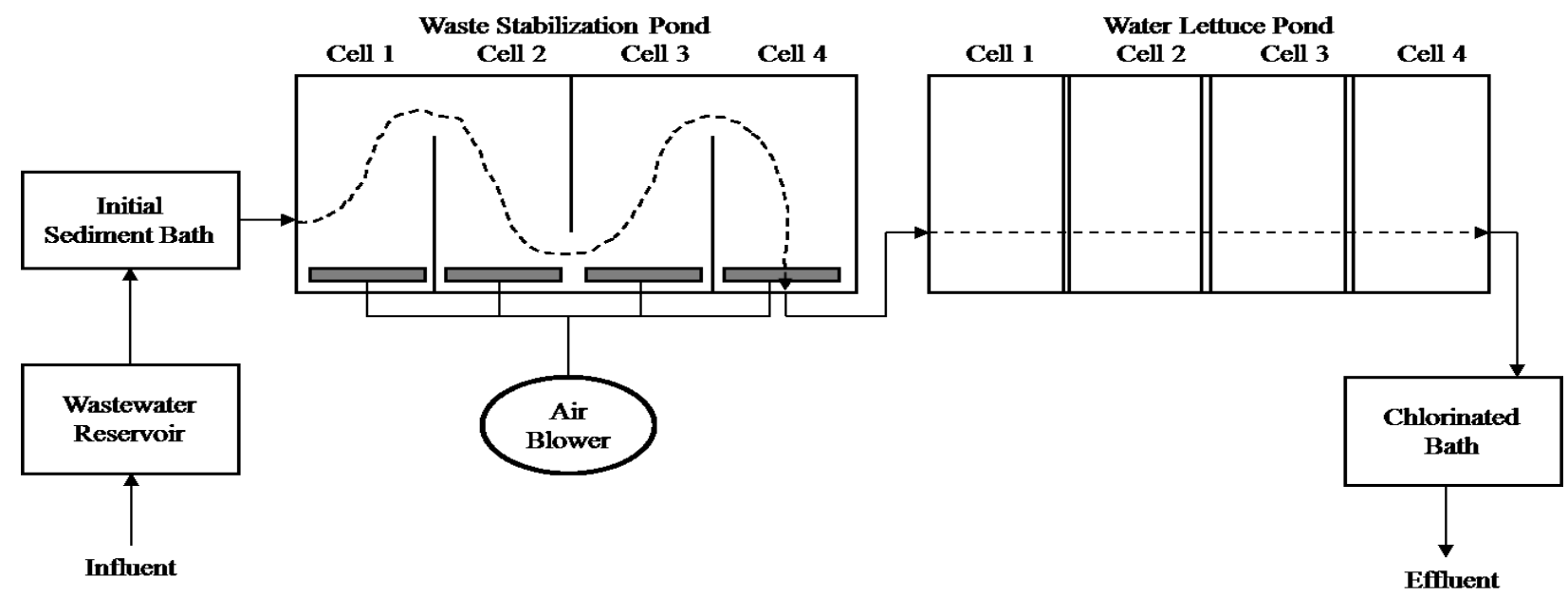

Fig. 1. Pilot System Layout

The Water Lettuce pond is the name for a pond filled with floating aquatic plants, similar to lettuce, the apu woods that have the latin name Pistia Stratiotes. The apu wood plants have long, dangling roots such as the hair that hangs in the water [7]. At the root of this plant occurs the process of sedimentation and filtration that can reduce the number of particles of nitrogen and other compounds. In fact some people use this plant with soap to wash clothes, bowls and other household utensils [8]. The apu wood plants do not require such a vast growth medium and can multiply more rapidly because buds of apu wooden shoots emerge from the armpit of the parent's leaf, which can grow apart by having roots.

Previous research on the reduction of organic and inorganic compounds in wastewater using apu wood has also been done $[6,9]$. However, the weaknesses in the research are in the design and operation of ponds systems, due to lack of design and simulation methods as appropriate. Several studies related to the design and simulation methods which have been done, only on the facultative primary stabilization pool, maturation pond and facultative stabilization ponds planted with macrophytes, ie research of [10-12].

Therefore, this article provides a dynamic model that can be used to simulate the operation of a water lettuce pool. This model can be used to predict nitrogen decrease as well as nitrogen transformation processes in water lettuce pools integrated with waste stabilization ponds.

\section{Materials and Methods}

The pilot system integrating the waste stabilization pool with the apu pond is treating secondary waste in sewage treatment plants using an aerobically suspended culture (with air / dissolved oxygen). The suspended culture used is the most common and widely used, ie the process of processing with the standard activated sludge process. Wastewater treatment through active sludge process is chosen because it has the advantage, that is to treat wastewater with a large BOD (Biological Oxygen Demand) load, so it does not require a large place or pond. The wastewater treatment generally consists of an initial sediment bath, an aeration bath and a final settling bath, and a chlorination bath for killing pathogenic bacteria [13].

In this article, wastewater treatment consists of a wastewater reservoir, an initial sediment bath, an aeration bath (stabilization pool), a final sedimentary bath (a pumice pond) and a chlorinated bath. The waste stabilization pond and water lettuce pond are divided into four cells as shown in Figure 1.

\section{Development of Mathematical Models}

Biological waste processing is generally only a transformation process, not a purge. In all cases, it means the change of dissolved organic matter into particulate matter (bacterial colonies) which can then be removed by subsequent process steps, usually by sedimentation or filtration [14]. To construct the model, the following assumptions are given:

1. The process of nitrogen transformation is only in the water lettuce pond, as a refinement of the stabilization pond.

2. The process of nitrogen transformation is assumed to be a filtration process that produces sedimentation in which there are also several processes, namely hydrolysis, mineralization or amonification, nitrification, denitrification, bacterial uptake and plant uptake.

3. The process of hydrolysis, nitrification, denitrification occurs only at the root.

4. The apu wood and bacteria absorb ammonium and nitrate as a source of nitrogen. Nitrates and ammonium are the main sources of nitrogen that are key nutrients for plant growth [4].

5. Bacterial growth occurs in sedimentation. This is because bacteria tend to stick to sediments and other solid materials [4].

6. The waste flow rate in both the waste stabilization pool and the apu pond is assumed to be constant over time.

For the model system components shown in Table $\mathbf{1}$ and the conceptual model of the nitrogen transformation in the apu wooden pool can be shown in Figure 2. 


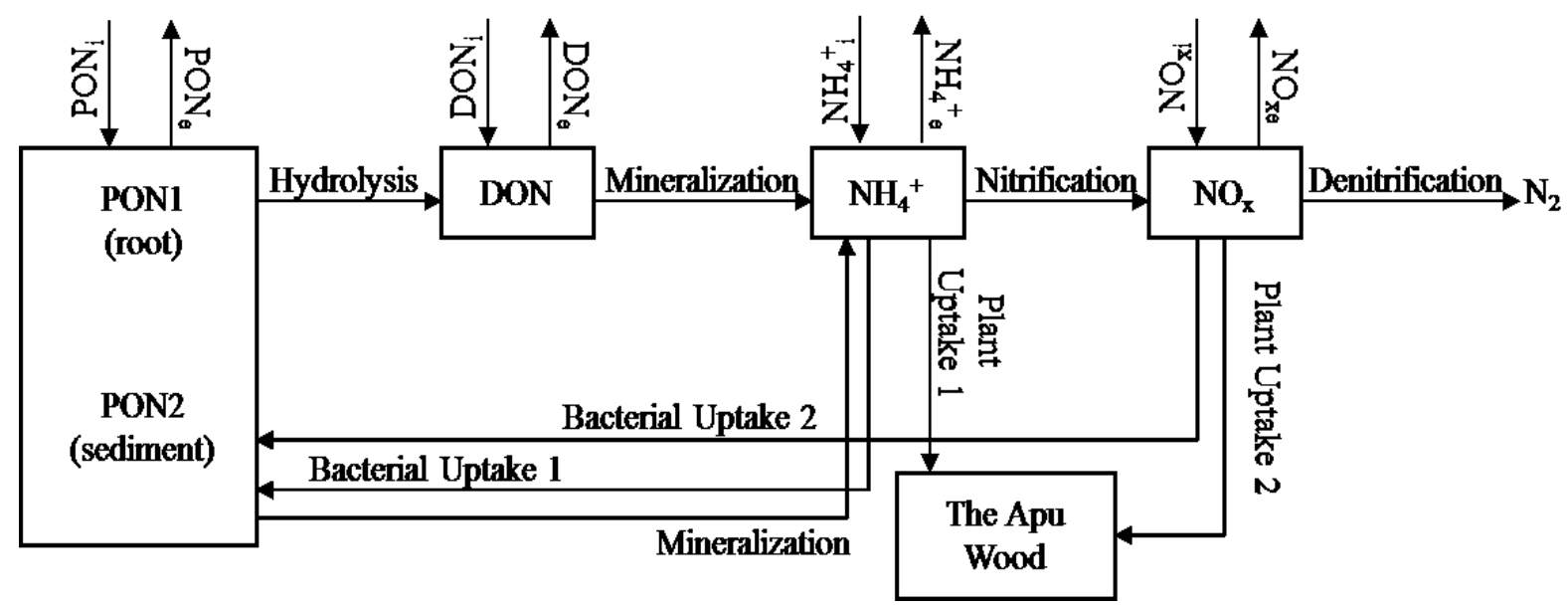

Fig. 2. Conceptual Model of Nitrogen Transformation in the Water Lettuce Pond

Table 1. System model components

\begin{tabular}{ll}
\multicolumn{1}{c}{ Symbol } & \multicolumn{1}{c}{ Definition } \\
\hline PON & Particulate Organic Nitrogen \\
DON & Dissolved Organic Nitrogen \\
$\mathrm{NH}_{4}^{+}$ & Concentration of Ammonium \\
NOx & Concentration of Nitrate and Nitrite \\
\hline
\end{tabular}

Consider from the actual natural, the phenomenon that affects the concentration is very complicated. The modeling requires some simplification to form a mathematical equation. That equation is a differential equation which is the rate of change or growth of a substance or species in the stabilization pond. Simplification is intended to limit the factors that affect the degradation process in ponds beginning with chemical reaction rate, biochemical reaction rate and growth rate of bacteria and plants. Based on Figure 2 and the above reaction rate equations, the model for predicting the components given in Table $\mathbf{1}$ are equation (1) to (4):

$$
\frac{d D O N}{d t}=\frac{Q}{V}\left(D O N_{i}-D O N_{e}\right)+r_{h}-r_{m 1}
$$

where the influent and effluent of the DON is described as $D O N_{i}$ and $D O N_{e} r_{h}$ is the rate of the process of PON hydrolysis and $r_{m+}$ is the rate of the process of DON mineralization.

Eq. (2) is used to predict the ammonium:

$$
\frac{d N H_{4}^{+}}{d t}=\frac{Q}{V}\left(\mathrm{NH}_{4}{ }^{+}{ }_{i}-\mathrm{NH}_{4}{ }^{+} \mathrm{e}\right)+r_{m 1}+r_{m 2}-r_{n}-r_{p}-r_{b}
$$

where $r_{m 2}$ is the rate of PON mineralization, $r_{n}$ is the rate of nitrification and $r_{p}, r_{b}$ are the rate of the plant and bacteria absorption.

The mass balance of nitrate and nitrite $\left(\mathrm{NO}_{\mathrm{x}}\right)$ is given by the following equation:

$$
\frac{d N O_{x}}{d t}=\frac{Q}{V}\left(N O_{x i}-N O_{x e}\right)+r_{n}-r_{d}-r_{p}-r_{b}
$$

where $r_{d}$ is the $N O_{x}$ denitrification rate.

$$
\frac{d P O N}{d t}=\frac{Q}{V}\left(P O N_{i}-P O N_{e}\right)+r_{b}-r_{h}-r_{m 2}
$$

The rate of process of hydrolysis and mineralization based on the biochemical transformation rate equation (Yi et al, 2009) are:

$$
\begin{gathered}
r_{h}=k_{h} \cdot P O N \\
r_{m 1}=k_{m 1} \cdot D O N \\
r_{m 2}=k_{m 2} \cdot P O N
\end{gathered}
$$

where $k_{h}, k_{m 1}, k_{m 2}$ are the constant rate of hydrolysis of PON, mineralization of DON and PON, respectively.

The nitrification process rate equation is built from the growth of nitrifying bacteria dependent on the $\mathrm{pH}$, temperature, and concentration of ammonia and dissolved oxygen [10-11], as follows:

$$
r_{n}=\frac{\mu_{n}}{Y_{n}}\left(\frac{\mathrm{NH}_{4}^{+}}{\mathrm{K}_{1}+\mathrm{NH}_{4}^{+}}\right)\left(\frac{D O}{K_{2}+D O}\right) C_{T} C_{p H}
$$

where $\mu_{n}$ is the maximum growth rate of nitrifying bacteria, $Y_{n}$ is the yield coefficient/production rate of nitrification bacteria, $K_{1}, K_{2}, \mathrm{C}_{\mathrm{T}}$ and $C_{p H}$ are the saturation constant of bacteria that depends on temperature and oxygen, a nitrifying rate that depends on temperature and $\mathrm{pH}$, respectively.

The denitrification process rate equations are modeled using the first-order Arrhenius kinetic equation [10-11] as follows:

$$
r_{d}=R 2{ }_{20} \theta^{(T-20)} N O_{x}
$$

where $R 2_{20}$ is denitrification constant, $\theta$ is Arrhenius constant and $T$ is temperature.

The equation of bacteria and plant absorption rate, modified from $[5,10-11]$ based on the monod equation, as follows:

$$
r_{b}=\mu_{b}\left(i_{N B} Y_{A}+i_{N B} Y_{H}\right)
$$

$i_{N B}=\left\lceil\frac{\mathrm{NH}_{4}{ }^{+}}{\mathrm{K}^{+} \mathrm{NH}_{4}^{+}}\right\rceil P O N$ atau $i_{N B}=\left\lceil\frac{N O_{x}}{K+N O_{x}}\right\rfloor P O N$

$$
r_{p}=i_{N P} g_{p}
$$




$$
i_{N P}=\frac{N H_{4}^{+}}{K+N H_{4}^{+}} \text {atau } i_{N P}=\frac{N O_{x}}{K+N O_{x}}
$$

where $\mu_{b}$ is the maximum growth rate of bacteria, $g_{p}$ is the maximum growth rate of plant, $i_{N B}, i_{N P}$ are nitrogen content absorbed by bacteria and plant, $Y_{A}, Y_{H}$ are level of production of autotrophic and heterotrophic cells and $K$ is the saturation constant for ammonium or nitrite/nitrate.

\section{Results and Discussions}

To find out the system behavior of equations (1), (2), (3) and (4) we need the values of the model parameters which can be seen in Table 2 .

Table 2. Model Parameters

\begin{tabular}{|c|c|c|c|}
\hline \multicolumn{2}{|c|}{ Parameters } & Value & Source \\
\hline & $Y_{A}$ & 0.24 & {$[5]$} \\
\hline & $Y_{H}$ & 0.67 & [5] \\
\hline \multirow[t]{3}{*}{ First-order rate } & $k_{H}$ & 0.01 & {$[15]$} \\
\hline & $k_{m 1}$ & 0.1 & {$[15]$} \\
\hline & $k_{m 2}$ & 0.1 & {$[15]$} \\
\hline \multirow[t]{2}{*}{ Bacteria } & $\mu_{b}$ & 0.18 & {$[10]$} \\
\hline & $K$ & $1.8^{\mathrm{a}}, 2.0^{\mathrm{b}}$ & {$[10]$} \\
\hline \multirow[t]{2}{*}{ Plant } & $g_{p}$ & 0.5 & {$[5]$} \\
\hline & $K$ & $1.8^{\mathrm{a}}, 2.0^{\mathrm{b}}$ & {$[10]$} \\
\hline \multirow[t]{7}{*}{ Nitrification } & $\mu_{n}$ & 0.008 & {$[10]$} \\
\hline & $Y_{n}$ & 0.13 & {$[10]$} \\
\hline & $K_{1}$ & $1^{(0.051(\mathrm{~T}-1.58)) \mathrm{c}}$ & {$[10]$} \\
\hline & $K_{2}$ & 1.3 & {$[10]$} \\
\hline & $C_{T}$ & $e^{0.098(1-15) c}$ & {$[10]$} \\
\hline & $C_{p H}$ & $1.0^{\mathrm{d}}$ & {$[10]$} \\
\hline & & $1-0.833(7.2-\mathrm{pH})^{\mathrm{e}}$ & {$[10]$} \\
\hline \multirow[t]{2}{*}{ Denitrification } & $R 2_{20}$ & 0.1 & {$[10]$} \\
\hline & $\theta$ & 1.02 & {$[10]$} \\
\hline $\begin{array}{l}\text { a ammonium } \\
\text { b nitrite/nitrate } \\
{ }^{c} \text { depend on the }\end{array}$ & erature & & \\
\hline \multicolumn{3}{|c|}{${ }^{\mathrm{d}}$ If $\mathrm{pH} \geq 7.2$} & \\
\hline
\end{tabular}

The solution graph of the nitrogen reduction system (DON, $\mathrm{NH}_{4}^{+}, \mathrm{NO}_{\mathrm{x}}$ and PON) is given in Figures 3 to 7 .

Based on Figure 3, it can be seen that the rate of change in the concentration of nitrogen compounds (DON, PON, $\mathrm{NH}_{4}^{+}$, and $\mathrm{NO}_{\mathrm{x}}$ ) in ponds that integrate the waste stabilization pool and water lettuce ponds decreases. Figure 4 showed that the dissolved organic nitrogen (DON) compound decreases until it reaches stable around the 80th day. However, for particulate organic nitrogen (PON) seen on Figure 5, the first 10 days increased up to $35 \mathrm{mg} / \mathrm{l}$ and then decreased until it reached stability on the 80 th day as well.

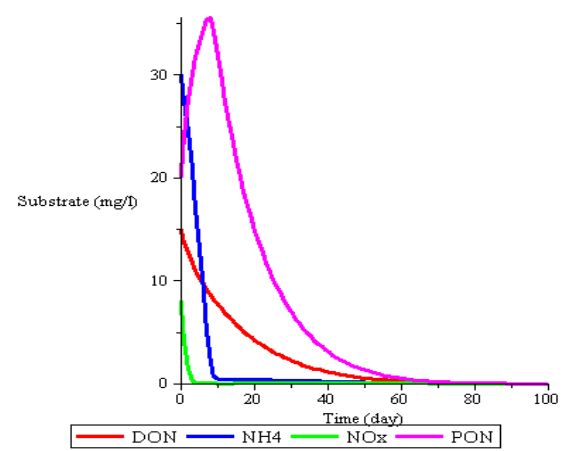

Fig. 3. Behavior of Substrate Concentration

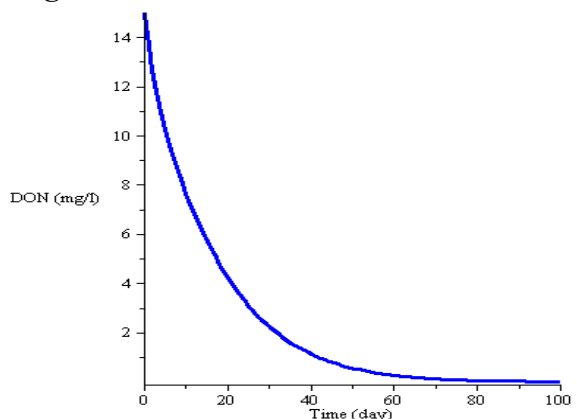

Fig. 4. Behavior of Dissolved Organic Nitrogen Concentration

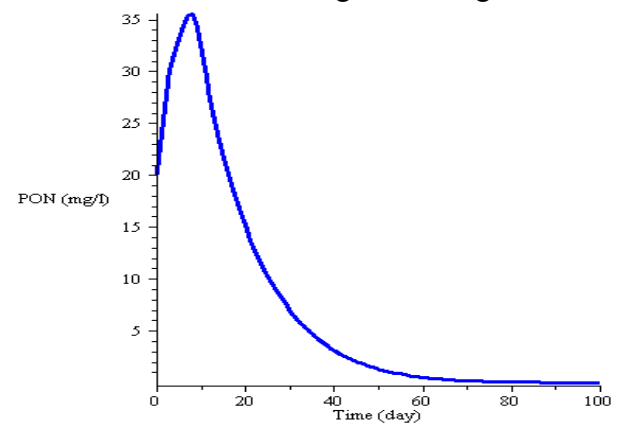

Fig. 5. Behavior of Particulate Organic Nitrogen Concentration

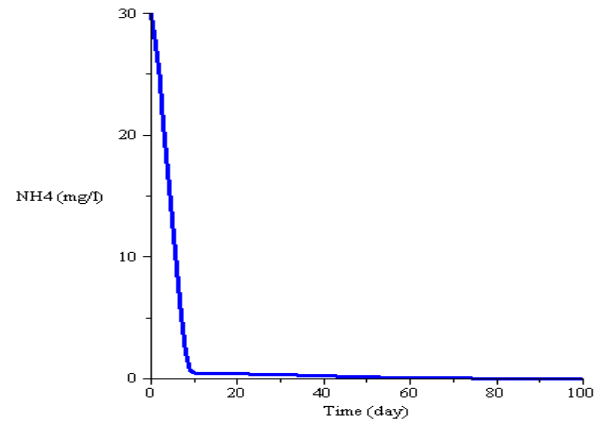

Fig. 6. Behavior of Ammonium Concentration

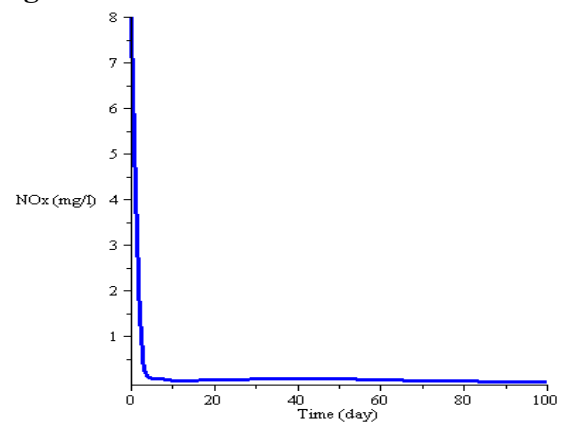

Fig. 7. Behavior of Nitrite/Nitrate Concentration 
This is thought to be caused by bacteria. Bacteria decomposed dead animals or vegetation into several organic compounds, including organic nitrogen compounds, causing organic nitrogen to increase rapidly. However, with the process of sewage treatment designed in such a way, for example by aerator, conventional active sludge system, the bacteria switch function to convert organic compounds into inorganic and can be utilized by other living things, including himself. Thus, the inorganic nitrogen that was originally increased, over time becomes decreased and stable, so it can be channeled into the vast waters. The question arises, why not so with dissolved organic nitrogen? This is because bacteria are usually inside solids / particulates or in sedimentation (sediment).

For inorganic nitrogen compounds, both ammonium $(\mathrm{NH} 4+)$ and nitric-nitrite (NOx) as shown on Figure 6 and Figure 7 decreased until reach stability at a faster time than organic compounds, ie at about day 10 and day 5. Based on these results, the wastewater treatment by integrating the waste stabilization pond and the water lettuce pond can be said to be capable of assisting in the case of the reduction of nitrogen compounds.

\section{Conclusions}

Based on the results and discussion, it can be seen that the rate of change in the concentration of nitrogen compounds in the integration pond of waste stabilization and water lettuce decreases and reaches stable at different times. This suggests that a pond of waste stabilization integrated with a water lettuce pond provides a good effect in the reduction and transformation of nitrogen.

\section{References}

1. P. G. Smith, J. G. Scott, Dictionary of Water and Waste Management (IWA publishing, London, 2002)

2. O. A. M. Lewis, Plants and Nitrogen (Edward Arnold Ltd, London, 1986)

3. M. Negulescu, Municipal Waste Water Treatment (Elsevier Science, New York, 1985)

4. H. Effendi, Telaah Kualitas Air Bagi Pengelolaan Sumber Daya dan Lingkungan Perairan (Kanisius, Yogyakarta, 2003)

5. Q. Yi, H. C. Hur, Y. Kim, Eco. Eng. 35, 75-84 (2009)

6. S. A. Mustaniroh, Wignyanto, E. S. Bernardus, J. Tekn. Pert. 10, 10-18 (2009)

7. W. S. Don, E. Threes, H. Cherry, Tanaman Air (Gramedia Pustaka Utama, Jakarta, 2000)

8. O. C. Hean, Tanaman Hiasan Khasiat Makanan dan Ubatan (Yeohprinco SDN. BHD, Kuala Lumpur, 2006)

9. H. I. Owamah, M. A. Enaboifo, O. C. Izinyon, Agri. Wat. Manage. 146, 262-269 (2014)

10. M. A. Senzia, A. W. Mayo, T. S. A. Mbwette, J. H. Y. Katima, S. E. Jørgensen, Eco. Model. 154, $207-$ 215 (2002)

11. W. A. Mayo, M. Abbas, Phy. and Chem. Earth. 7275, 77-82 (2014)

12. S. M. Grau, A. G. Sfinchez, J. M. Clavel, J. S. Aniorte, M. D. M. Grau, Eco. Model. 91, 77-103 (1996)

13. N. S. Idaman, Pengolahan Air Limbah Domestik di DKI Jakarta (Badan Pengkajian dan Penerapan Teknologi, Jakarta, 2008)

14. A. S. Siregar, Instalasi Pengolahan Air Limbah (Kanisius, Yogyakarta, 2005)

15. B. Beran, F. Kargi, Eco. Model. 181, 39-57 (2005) 